\title{
Rotterdam 2004
}

\author{
By Gönül Dönmez-Colin
}

Fall 2004 Issue of KINEMA

\section{INTERNATIONAL FILM FESTIVAL ROTTERDAM 2004}

Thirty third International Film Festival Rotterdam (21 Jan - 1 Feb 2004) offered a wide selection of films for the VPRO Tiger Awards Competition. A wonderful surprise from China was Zhifu (Uniform), debut feature of Diao Yinan, a digital film set in an industrial city in a remote part of China. The protagonist who has a small job in laundry tries to have his sick father receive pension from the closed down factory but gets nowhere. One day, he comes across an unclaimed police uniform and his life takes a new direction. Picking up a nice girl is not a problem when he wears the uniform. He even manages to earn extra cash by receiving bribes. The anti-hero's fall is evident from the start but what makes the film special is its depiction of a China less explored on the screen. The portrayal of the policeman is certainly very different than what we have seen a few years ago in the film of Ning Ying, On the Beat (1995).

On the same continent, Lee Kang-sheng's debut feature after twelve years of acting, particularly as the protagonist of most films of Tsai Ming-liang, Bu jian (The Missing) was as melancholy as it would befit Lee's image in those films. In fact, both filmmakers have admitted that a certain link exists between Tsai Ming-liang's Goodbye Dragon Inn and Lee Kang-sheng's The Missing. For instance, both focus on a tightly framed space in Taipei. Lee's film is about loss- a woman losing the child in her care, a young man losing his grandfather and the existential loss human beings experience each day in a modern world.

The Wooden Camera, the second feature of Ntshaveni Wa Luruli from South Africa carried the same humour as his first feature, Chikin Biznis while drawing a realistic portrayal of life in the townships.

From Europe, Kako ubiv svetec (How I Killed a Saint) by Teona S. Mitevska, the story of a young woman's dilemma when she returns from America to her family in conflict ridden Macedonia was testimony to a new generation of Balkan filmmakers who are trying to attach some meaning to the turmoil that have had devastated the region. Srdjan Vuletić's Ljeto u zlatnoj dolini (Summer in the Golden Valley), about two adolescents condemned to a no future situation in Sarajevo was also about the uncertainties facing the new generation who try to cope with the aftermath of war and destruction.

Among the films that were made in thepast year with assistance from the Hubert Bals Fund, Afghani Barmak Sedigh's Osama about a twelve year old girl dressed as a boy to support her family in her war ridden country, has been an international success, just like Uzak (Distant) by Turkish Nuri Bilge Ceylan, a film about personal space, physical, intellectual and even sexual borders and how these relate to one's environment and how the environment in return shapes one's preconceptions. The first Turkish film to win a prize at the Cannes Film Festival since Yol, the film has been an important step for Turkish cinema, which has spent most of the nineties trying to find a certain identity or direction.

In the same section, Man Yan (Pirated Copy) by He Jianjun from Beijing, who has worked with masters such as Chen Kaige, Zhang Yimou and Tian Zhuangzhuang and has become one of the most important voices of the sixth generation Chinese cinema, was a very sharp documentary on the illegal sales of DVDs. Taking place during a cold winter day in Beijing, the film introduces an incredible melange of characters such as an unemployed couple who find an outlet for their frustrations by watching Pulp Fiction but meet disappointment when they try to imitate art in life.

Abolfazl Jalili's Abjad (The First Letter) was a candid autobiographical work about growing up gifted in the restricted and repressive atmosphere of Iran. Nariman Turebayev's Malen'kie ljudi (Little Men) gave a pungent eye view of Almaty, the cultural capital of Kazakhstan where the market economy arrived too fast. A story of two young man, an extrovert Russian and a shy Kazakh who try to keep up with the times by doing odd jobs and cruising women in between, the film tries to send its message by visual images rather than extensive dialogue. 
In the main program, from controversial Catherine Breilllat's Anatomie de l'enfer (Anatomy of Hell) to Cannes favourite Les invasions barbares (The Barbarian Invasions) by Denys Arcand, the list of films one wanted to see went beyond the critics' usual maximum four-film-a-day schedule. There were several not to be missed gems. For instance, from Japan Hiroki Ryuichi's post modern, post punk, post anything revelation on mismatched relationships, with a catchy title, Vibrator; again from Japan exceptional talent Kawase Naomi's sensitive Shara soju, Kitano Takeshi's Zatoichi, not to forget Canada's own Guy Maddin's wild The Saddest Music in the World.

In the Cinema Regained section, the first cut of John Cassavetes's Shadows and King Hu's Dragon Inn, shown with the Dragon Inn of Tsai Ming-liang; short films, Nigerian videos of Tunde Kelani; Raul Ruiz whom Adrian Martin calls "the poet laureate of cinematic excess;" post-9/11 America and last but not the least, Romani Cinema - the Gypsy in film - completed a program that was rich and diverse.

Rotterdam is not all about screenings of films of course. The Cinemart is very active as it is most likely that everyone who is someone in the business is bound to be there; then the Hubert Bals Fund given in remembrance of one of the directors of the festival who passed away, to promising projects from developing countries, but most of all Rotterdam is about atmosphere. The city folk along with the professionals run to the theatres starting 9 am and are reluctant to leave until past midnight, not to miss the films from countries they may never have visited, or talk shows and other exciting gatherings that bring cine buffs together.

\section{References}

\section{AWARDS}

VPRO Tiger Awards

Bu jian (The Missing) by Lee Kang-sheng (Taiwan)

Ljeto u zlatnoj dolini (Summer in the Golden Valley) by Srdjan Vuletić (Bosnia-Herzegovina-France-United Kingdom)

En Route by Jan Kruger (Germany)

FIPRESCI (Federation of International Film Critics)

Peep "TV" Show by Yutaka Tsuchiya

KNF (Dutch Critics)

Bu jian (The Missing) by Lee Kang-sheng (Taiwan)

NETPAC (Network to promote Asian cinema)

Bu jian (The Missing) by Lee Kang-sheng (Taiwan)

Amnesty International

Posledny poezd (The Last Train) by Alexei German Jr (Russia)

\section{Author Information}

Gönül DÖNMEZ-COLIN is an independent researcher and writer whose publications include Women, Islam and Cinema, Cinemas of the Other: A personal Journey with Filmmakers from the Middle East and Central Asia, Cinema of North Africa and the Middle East (ed.); Turkish Cinema: Identity, Distance and Belonging (Reaktion Books), and Routledge Dictionary of Turkish Cinema (2014). 